\title{
DISSERTAÇÕES
}

\section{Percursos na teoria das práticas sociais: Anthony Giddens e Pierre Bourdieu}

Gabriel Moura Peters

Curso: Mestrado em Sociologia

Data de defesa: 25 de janeiro de 2006

Orientador: Prof. Dr. Luís Augusto S. Cavalcanti de Gusmão

\section{Resumo}

O trabalho desenvolve uma exegese dos quadros teóricometodológicos de análise da vida social avançados por Pierre Bourdieu e Anthony Giddens, concentrando-se nas formas pelas quais cada um desses autores ataca o problema fundacional da relação entre os planos da agência e da estrutura, tomados como as duas dimensões essencialmente constitutivas de qualquer retrato ou investigação do universo societário.

O exame de tal problemática justifica-se pelo fato de que a teoria da prática de Bourdieu e a teoria da estruturação de Giddens têm como alicerce comum a tentativa de superação de um espectro de dicotomias inter-relacionadas que atravessam a história do pensamento científico-social no século XX, tendo sido expressas por uma variedade de rótulos binomiais, tais como subjetivismo/ objetivismo, individualismo/holismo e micro/macro. A investigação das inovações conceituais e teses sociontológicas desenhadas nas teorias dos autores supracitados é situada contra o pano de 
fundo de uma apresentação de tais antinomias, as quais indicam a tendência, corporificada em uma impressionante diversidade de perspectivas teórico-metodológicas, à formulação de concepções do relacionamento entre a ação individual subjetivamente propelida, de um lado, e as propriedades estruturais ou institucionais de formações coletivas, de outro, nas quais uma primazia explanatória é aprioristicamente imputada a uma destas esferas.

Nesse sentido, o foco da exposição das armaduras teóricoanalíticas de Giddens e Bourdieu se dirige ao elenco dos argumentos pelos quais ambos buscam demonstrar os limites de soluções teóricas unilaterais ao problema da articulação entre as instâncias da agência e da estrutura, ao mesmo tempo em que tecem instrumentos heurísticos orientados precisamente no sentido da captura da relação de condicionalidade recíproca estabelecida entre as mesmas no desenrolar da existência sócio-humana.

Esse percurso exegético desemboca, por fim, na conclusão de que a teoria da prática e a teoria da estruturação consistem em versões distintas de um modelo praxiológico-estruturacionista de investigação do mundo social, um enfoque que tem como pedra de toque a tese (trivial apenas à primeira vista) de que a caracterização da vida societária como fluxo ininterrupto de práticas configurase como o ponto de partida heuristicamente mais fecundo para a construção de um retrato acurado dos processos simultâneos de constituição da sociedade pelos agentes e de constituição dos agentes pela sociedade.

Palavras-chave: práticas sociais, estrutura social, ação, teoria sociológica, Anthony Giddens, Pierre Bourdieu. 